\title{
The Influence of a Humectant on the Retention by Humans of Solanesol from Cigarette Smoke (Part 1, Propylene Glycol)*
}

\author{
by \\ Serban C. Moldoveanu, William M. Coleman III \\ R.J. Reynolds Tobacco Co., 950 Reynolds Blvd., Winston-Salem, NC 27105 USA
}

\section{SUMMARY}

Propylene glycol (PG) is a common humectant added to the tobacco used in cigarettes, and part of this compound is transferred to smoke. The influence of this additive on the retention of solanesol by smokers has been evaluated in the present study for two cigarettes having the same tobacco blend except for the $3 \%$ addition of PG on one of them. The cigarette with no PG was a commercial brand, and the experimental one was made using the same tobacco blend as the commercial cigarette, but adding $3 \%$ of PG. The construction of the cigarette with 3\% PG allowed to match as close as possible the 'tar' [as measured by Federal Trade Commission (FTC) regimen], pressure drop (open and closed), and nicotine level of the commercial cigarette. The number of human subjects taking the test was ten smokers for each of the two evaluated products. The sample collection was performed from three cigarettes smoked within one hour. The same human subject smoked the regular cigarette and then the one with added PG. The exhaled smoke was collected using a vacuum assisted procedure that avoids strain in exhaling, and the solanesol was analyzed using an high performance liquid chromatography (HPLC) technique. The cigarette butts from the smokers were collected and also analyzed for solanesol. The results obtained for the cigarette butts from the smokers were used to calculate the level of solanesol in the smoke delivered to the human subject, based on calibration curves. These curves were generated separately by analyzing the solanesol in smoke and in the cigarette butts obtained by machine smoking under different puffing regimes. Knowing the delivered amount of solanesol and that in the exhaled smoke it was possible to calculate the retention of this compound from mainstream smoke for the two cigarette types. The levels of solanesol delivered to the smoker from Cigarette A was in the range between 350.4 $\mu \mathrm{g} / \mathrm{cig}$ and $504.8 \mu \mathrm{g} / \mathrm{cig}$ for the cigarette with no PG, and between $401.5 \mu \mathrm{g} / \mathrm{cig}$ and $614.1 \mu \mathrm{g} / \mathrm{cig}$ for the cigarette with $3 \%$ PG added. The amount of solanesol retained by the smoker (per cigarette) was on an average $309 \mu \mathrm{g} / \mathrm{cig}$ with $15.8 \%$ relative standard deviation for the cigarette with no PG, and an average of $348 \mu \mathrm{g} / \mathrm{cig}$ with $20.4 \%$ relative standard deviation for the $3 \% \mathrm{PG}$ cigarette. An ANOVA single factor analysis showed that the results between the two cigarettes were not statistically different for $95 \%$ confidence. The retention of solanesol from the commercial cigarette showed an average of $72.5 \%$ with $11.7 \%$ relative standard deviation, and the cigarette with $3 \%$ added $\mathrm{PG}$ showed an average retention of $70.8 \%$ with $14.5 \%$ relative standard deviation. ANOVA single factor analysis indicated no significant differences in the retention $\%$ of solanesol for the two cigarettes at $95 \%$ confidence. No correlation was found between the amount of solanesol delivered from the cigarette to the smoker and the solanesol retained \%. [Beitr. Tabakforsch. Int. 23 (2008) 153-159]

\section{ZUSAMMENFASSUNG}

Propylenglykol (PG) ist ein gebräuchliches Feuchthaltemittel, das dem Zigarettentabak hinzugefügt wird. Ein Teil dieser Substanz geht in den Rauch über. Der Einfluss dieses Additivs auf die Solanesolretention bei Rauchern wurde in dieser Studie bei zwei Zigarettensorten untersucht, die die gleiche Tabakmischung enthielten. Einer der beiden Zigarettensorten wurden 3\% PG zur Mischung zugesetzt. Bei der Zigarette ohne $P G$ handelte es sich um eine handelsübliche Zigarette. Die experimentelle Zigarette 
wurde so konstruiert, dass sie annähernd die gleichen Kondensatwerte (entsprechend der Abrauchnormen der Federal Trade Commission), den gleichen Zugwiderstand (offen und geschlossen) und Nikotingehalt wie die auf dem Markt erhältlichen Vergleichszigaretten aufwies. Jeweils zehn Raucher rauchten die beiden Zigarettenarten. Die Probenahme erfolgte bei drei Zigaretten, die pro Stunde geraucht wurden. Dieselben Raucher rauchten sowohl die regulären als auch die Testzigaretten, denen PG hinzugefügtt worden war. Der exhalierte Rauch wurde in einem Vakuum-unterstützten Verfahren gesammelt, um einen Widerstand beim Exhalieren zu vermeiden. Das Solanesol wurde mittels Hochdruck-Flüssigkeitschromatographie (HPLC) bestimmt. Die Zigarettenkippen der Raucher wurden eingesammelt und ebenfalls auf ihren Solanesolgehalt untersucht. Anhand der Werte in den Zigarettenkippen wurden die mit dem Rauch an die Raucher abgegebene Solanesolmenge auf der Basis von Kalibrationskurven berechnet. Diese Kurven wurden unabhängig generiert, indem die Solanesolkonzentration im Rauch und in den Zigarettenkippen durch maschinelles Abrauchen unter verschiedenen Abrauchnormen ermittelt wurde. Ist die abgegebene Solanesolmenge und der Solanesolanteil im exhalierten Rauch bekannt, ist es möglich, die Retention dieser Substanz durch den Raucher für beide Zigarettentypen zu berechnen. Bei der Zigarette A, die kein PG enthielt, lag die vom Raucher retenierte Solanesolmenge zwischen 350,4 und 504,8 $\mu \mathrm{g}$ /Zigarette. Bei der Zigarette, der 3\% PG zugesetzt worden waren, lag dieser Wert zwischen 401,5 und 614,1 $\mu \mathrm{g}$ /Zigarette. Der Solanesolanteil, der vom Raucher (pro Zigarette) reteniert wurde, lag bei durchschnittlich $309 \mu \mathrm{g} /$ Zigarette mit einer relativen Standardabweichung von 15.8\% für die Zigarette ohne Zusatz von PG und bei durchschnittlich 348 $\mu \mathrm{g} /$ Zigarette mit einer relativen Standardabweichung von 20.4\% für die Zigarette mit Zusatz von 3\% PG. Die Einfaktorielle Varianzanalyse zeigte, dass die Unterschiede zwischen beiden Zigaretten bei einem 95\%gen Konfidenzintervall statistisch nicht signifikant waren. Die Solanesolretention lag bei der im Handel erhältlichen Zigarette bei durchschnittlich 72,5\% mit einer relativen Standardabweichung von 11,7\%. Die Zigarette mit Zusatz von PG wies eine durchschnittliche Retention von $70,8 \%$ mit einer relativen Standardabweichung von $14,5 \%$ auf. Die Varianzanalyse zeigte zwischen beiden Zigaretten auf dem 5\%-Signifikanzniveau keine Unterschiede bei der Retention von Solanesol. Zwischen der aus der Zigarette an den Raucher abgegebenen Solanesolmenge und der prozentualen Solanesolretention wurde keine Korrelation festgestellt. [Beitr. Tabakforsch. Int. 23 (2008) 153-159]

\section{RESUME}

Le propylène glycole (PG) est un humectant fréquemment apporté au tabac de cigarette, dont une partie de ce composé est transféré dans la fumée. L'influence de cet additif sur la rétention du solanésol chez les fumeurs a été évaluée dans l'étude présente, sur la base de deux cigarettes ayant le même mélange de tabac à l'exception de $3 \%$ de PG apporté à une ces cigarettes. La cigarette sans $\mathrm{PG}$ est disponible sur le marché, la cigarette expérimentale a été construite avec le même mélange de tabac comme la cigarette du marché, mais avec l'apport supplémentaire de $3 \%$ de PG. La cigarette contenant 3\% de PG a été construite de façon à correspondre le plus près possible aux valeurs de goudron [mesurées sous les conditions normalisées de la Federal Trade Commission (FTC)], perte de charge (ouvert et fermé), et le taux de la nicotine de la cigarette commerciale. Dans cette étude, dix fumeurs ont fumé les deux cigarettes évaluées. La fumée a été échantillonnée de trois cigarettes fumées en une heure. Les mêmes fumeurs ont fumé les cigarettes régulières et les cigarettes contenant du PG. La fumée exhalées a été collectée à l'aide d'une technique sous vide pour éviter une trop grande résistance durant l'exhalation de la fumée, et le solanésol a été dosé par chromatographie en phase liquide à haute performance (HPLC). Les mégots de cigarette ont été collectés et également dosés pour leur teneur en solanésol. A partir des résultats obtenus pour les mégots et à l'aide des courbes d' étalonnage normalisée, la teneur en solanésol dans la fumée délivrée au fumeur a été calculée. Ces courbes ont été générés séparément en dosant la teneur en solanésol dans la fumée et dans les mégots, obtenue par fumage sur machine. La connaissance du taux du solanésol délivré et sa teneur dans la fumée, a permis de calculer la rétention de ce composant de la fumée principale pour les deux cigarettes. La teneur en solanésol délivrée au fumeur s'élève de 350,4 à $504,8 \mu \mathrm{g}$ /cigarette pour la cigarette A sans apport de $\mathrm{PG}$, et de 401,5 à $614,1 \mu \mathrm{g} /$ cigarette pour la cigarette avec apport de 3\% de PG. La teneur en solanésol retenue par le fumeur (par cigarette) est en moyenne 309 $\mu \mathrm{g} /$ cigarette, avec un écart type relatif de $15,8 \%$ pour la cigarette sans PG et en moyenne $348 \mu \mathrm{g} /$ cigarette avec un écart type relatif de $20,4 \%$ pour la cigarette avec apport de $3 \%$ de PG. Une analyse statistique ANOVA à un facteur a révélé que les résultats obtenus pour les deux types de cigarettes ne sont pas statistiquement différents au niveau de confiance de $95 \%$. La rétention du solanésol dans la cigarette commerciale a en moyenne $72,5 \%$ avec un écart type relatif de $11,7 \%$, et la cigarette avec $\mathrm{PG}$ a une rétention moyenne de $70,8 \%$ avec un écart type relatif de $14.5 \%$. L'analyse statistique ANOVA n'a pas révélé des différences significatives pour la rétention du solanésol entres les deux cigarettes au niveau de confiance de 95\%. Une corrélation entre le taux du solanésol délivré de la cigarette au fumeur et le pourcentage du solanésol retenu n’a pas été trouvé. [Beitr. Tabakforsch. Int. 23 (2008) 153-159]

\section{INTRODUCTION}

Solanesol is present in tobacco and in cigarette smoke, and has been considered a good marker for the particulate phase of environmental tobacco smoke (ETS) (1-3). This choice was made in part because the compound is non-volatile (molecular weight $\mathrm{MW}=631.10$ ), and also, because tobacco smoking can be considered the unique source of this substance in the environmental aerosols (although solanesol is present in other plants from Solanaceae family). The retention by humans of solanesol from ETS has been previously studied with results showing retention values between $20 \%$ and $57 \%$ (with an average of $40 \pm$ 
Table 1. Description of tested cigarettes

\begin{tabular}{l|c|c}
\hline Descriptor & $\begin{array}{c}\text { Cig A } \\
\text { Commercial }\end{array}$ & $\begin{array}{c}\text { Cig B } \\
\text { Experimental with 3\% PG }\end{array}$ \\
\hline FTC 'tar' (mg/cig) & 10.2 & 10.1 \\
TPM $^{\text {a }}$ (mg/cig) & 12.2 & 12.1 \\
Cigarette length (mm) & 83 & 83 \\
Filter length (mm) & 27 & 27 \\
Filter ventilation (\%) & 29 & 29 \\
Blend type & 'American' & 'American' b \\
Nicotine (mg/cig) & 0.91 & 0.85 \\
CO (mg/cig) & 10.6 & 10.2 \\
Smoke propylene glycol & $<0.04$ & 0.68 \\
$\quad$ (mg/cig) & & \\
Smoke glycerin (mg/cig) & 0.28 & 0.27 \\
Open draft (mm) & 106 & 100 \\
Closed draft (mm) & 132 & 129 \\
Tobacco weight (g) & 0.682 & 0.699 \\
\hline
\end{tabular}

a TPM = total particulate matter

${ }^{b}$ Same as Cigarette $A$.

$20 \%$ ) in males, and between $10 \%$ and $58 \%$ (with an average of $27 \pm 14 \%$ ) in females (4). The retention of solanesol was also studied for mainstream cigarette smoke in several recent studies. The first of these studies (5) evaluated the retention of solanesol from the mainstream of a $9.6 \mathrm{mg}$ 'tar' cigarette [measured using U.S. Federal Trade Commission (FTC) regimen (6)] on ten smokers using specific inhalation protocols, and the second study (7) evaluated the retention from three experimental cigarettes containing the additives diammonium phosphate (DAP) and urea. Both studies evaluated the delivered level of solanesol using a smoking duplicator. The first study indicated the retention of solanesol of $68.0 \pm 7.5 \%$ (for a $2 \mathrm{~s}$ breath-hold duration), and the second study showed a retention in the range of $65.1 \%$ to $70.7 \%$ for a $500 \mathrm{~mL}$ inhalation volume for the three evaluated cigarettes. Another recent study (8) evaluated the solanesol retention from three different cigarettes with FTC 'tar' values of $5.0 \mathrm{mg}, 10.6 \mathrm{mg}$, and $16.2 \mathrm{mg}$. For the 10.6 $\mathrm{mg}$ 'tar' cigarettes, the retention was found between $60 \%$ and $72 \%$, for the $5.0 \mathrm{mg}$ product the retention ranged between $53 \%$ and $70 \%$, and for the $16.2 \mathrm{mg}$ 'tar' product the retention ranged between $62 \%$ and $82 \%$, with no statistical difference between the $10.6 \mathrm{mg}$ 'tar' cigarette and the 16.2 $\mathrm{mg}$ 'tar' product. The retention \% for the $5.0 \mathrm{mg}$ 'tar' cigarette was found statistically different from the other two products.

Two other studies on solanesol retention from mainstream smoke were referenced in the literature (1), but the results were not published in peer reviewed journals, being only presented at meetings and not being readily available $(9$, 10). As reported in (1), in one of these studies (9) the average solanesol retention by humans was found to be about $48 \pm 8 \%$ (with inhalation at $15 \%$ of subject vital capacity), while in the other study the average reported retention was $58 \%$ for $250 \mathrm{~mL}$ inhalation volume and $61 \%$ for $500 \mathrm{~mL}$ inhalation volume (10). The lower retention result $48 \pm 8 \%$ obtained in one of the studies could be caused by the low inhalation volume $[15 \%$ of subject vital capacity, as compared to a typical inhalation volume of $25 \%$ from subject vital capacity (11)].
The deposition of cigarette smoke particles in the human respiratory track could be influenced by the hygroscopic growth of smoke particles. If this hypothesis is correct, different levels of a humectant in the smoke particles should influence smoke retention $(12,13)$. This present study was conducted to evaluate the potential influence of a humectant (PG) on solanesol retention. For this purpose, 3\% of PG was included in a blend identical to that of a commercial cigarette that does not contain PG. Each brand was evaluated on the same ten smokers. The smoking was performed in an environment familiar to the smoker (office) with as little change as possible from typical smoking conditions and with no control on the inhalation or exhalation patterns. The solanesol level delivered to the smoker was calculated based on the solanesol in the cigarette butts from the smokers, using calibration curves obtained in advance.

\section{EXPERIMENTAL}

Present study has been performed on two cigarettes, one being a commercial brand, and the other an experimental cigarette containing $3 \%$ of $\mathrm{PG}$ in a blend identical to that of the commercial one. The construction of the cigarette with $3 \%$ PG allowed to match as close as possible the 'tar' (as measured by FTC regimen), pressure drop (open and closed), and nicotine level of the commercial cigarette. The description of the cigarettes tested is given in Table 1.

To achieve the purpose of this study, it was necessary to find the levels of solanesol in the exhaled and in the smoke delivered to the human subject. Knowing the delivered and the exhaled levels of solanesol, it was possible to calculate the retention of this compound from mainstream smoke. The analysis of solanesol from the pads used for smoke collection (no solanesol is expected in the vapor phase smoke) and from $1 \mathrm{~cm}$ cut portion of the cigarette butts was performed by an high performance liquid chromatography (HPLC) procedure. The experimental part of this study consists of several steps, which include: 1) collection of particulate matter on Cambridge pads from the mainstream cigarette smoke obtained with a smoking machine using four different smoking regimens; the cigarette butts of the smoked cigarettes were retained for further solanesol analysis, 2) collection of particulate matter from the exhaled cigarette smoke; the cigarette butts of the cigarettes smoked by humans were also retained for solanesol analysis, 3) measurement of solanesol using an HPLC method in the pads and in $1 \mathrm{~cm}$ cut portion of the cigarette butts, and 4) calculation of the results. Each of these steps will be discussed in detail in sections that follow.

\section{Collection of samples from smoking machine}

Particulate matter was collected from five cigarettes on Cambridge pads using machine smoking under various regimens. The smoking was performed on a Borgwaldt rotary machine RM20/CSR (Hamburg, Germany) and included the following regimens: $35 \mathrm{~mL}$ puff volume, a puff duration of $1.5 \mathrm{~s}$ and each puff taken at $75 \mathrm{~s}$ interval (indicated as 35/75 regimen), $50 \mathrm{~mL}$ puff volume, a puff duration of $2 \mathrm{~s}$ and each puff taken at $30 \mathrm{~s}$ interval (indicated as 50/30 regimen), 55 $\mathrm{mL}$ puff volume, a puff duration of $2 \mathrm{~s}$ and each puff taken 


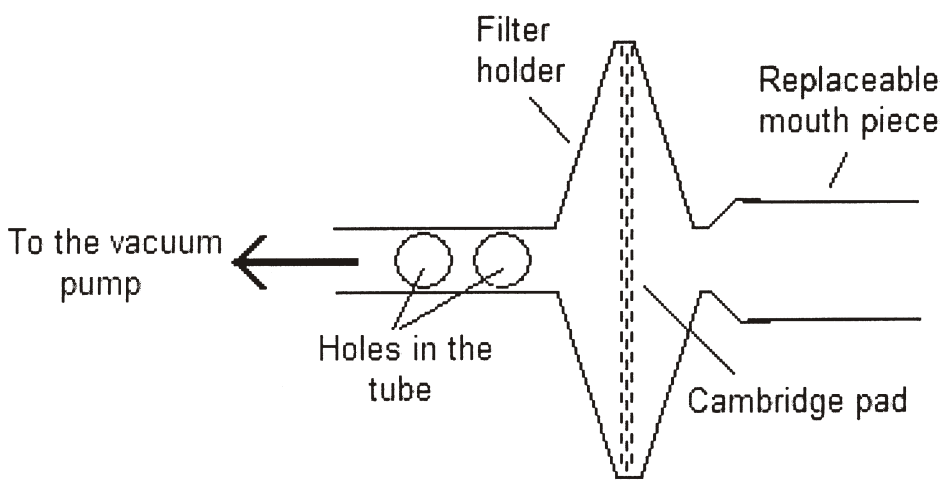

Figure 1. Device for the collection of exhaled cigarette smoke

at $80 \mathrm{~s}$ interval (indicated as 55/80 regimen), and $45 \mathrm{~mL}$ puff volume, a puff duration of $1.5 \mathrm{~s}$ and each puff taken at $40 \mathrm{~s}$ interval (indicated as 45/40 regimen). This variety of smoking regimens was selected in order to cover a range of flow rates in the cigarette filter that covers, at least in part, the flow rates similar to those noticed in human smoking (14). The cigarette butts from the cigarettes were also collected for the analysis of solanesol content. The butts were cut at $1 \mathrm{~cm}$ length from the mouth end, and this portion was used for the analysis of solanesol. The length of the cut portion of the cigarette butt was measured for ensuring that the length is precisely $1 \mathrm{~cm}$. A correction factor was applied when a small difference of the cut length was noticed.

\section{Exhaled smoke collection}

The collection of the exhaled smoke has been done using a simple device schematically shown in Figure 1. The device consisted of a $92 \mathrm{~mm}$ Cambridge pad holder and a pad having at one opening a replaceable mouth piece, and at the other opening being connected to a diaphragm vacuum pump, which can aspirate $2.2 \mathrm{~m}^{3} / \mathrm{h}$ (Vacuubrand GMBH, Wertheim, Germany). Through the pad and the connecting tubing, the pump achieves about $250 \mathrm{~mL} / \mathrm{s}$ flow. The tube connecting the pad holder to the pump had two large holes to the exterior, which can be covered with two fingers. When no smoke is exhaled, the holes in the tube to the vacuum pump were kept open such that surrounding air is aspirated by the pump without passing through the Cambridge filter. During exhalation of smoke, the smoker blows the smoke through the replaceable mouth piece. At the same time the two holes in the tube should be covered with two fingers, such that the exhaled smoke is aspirated through the Cambridge pad. This allows the exhaled smoke to be collected on the pad, without additional strain on the smoker. Considerable strain would be necessary otherwise to overcome the flow resistance of the Cambridge pad. The device shown in Figure 1 has been used by ten human subjects. Three cigarettes were smoked for each trial within one hour, and the exhaled smoke was collected on one pad. The cigarette butts were retained for solanesol analysis that was performed on $1 \mathrm{~cm}$ cut from the mouth end of the cigarette.

\section{High performance liquid chromatography analysis}

The analysis for solanesol in the particulate phase smoke collected on pads or on the cut portion of the cigarette butts was performed using an HPLC procedure (8). This procedure was similar in several respects with other procedures reported in the literature for solanesol analysis (15, 16). The procedure starts by extracting the pads or the cut portion of the cigarette butt with $20 \mathrm{~mL} n$-heptane containing $50 \mu \mathrm{g} / \mathrm{mL}$ pyrene (used as a chromatographic standard). A small volume of this solution (1-1.5 mL) was transferred to an LC vial and analyzed by HPLC using ultraviolet (UV) detection at $210 \mathrm{~nm}$, on an Agilent (Wilmington, DE) instrument (1050 HPLC with a diode array detector) equipped with a Spherisorb $5 \mu$ ODS (2) column (Waters, Milford, MA) $250 \times 4.6 \mathrm{~mm}$, and with an injection volume of $20 \mu \mathrm{L}$. The separation was performed in gradient conditions, as described in the literature (8).

\section{Calculation of the results}

Quantitation of solanesol was performed using a calibration curve relating the peak area from the chromatogram and the solution concentration. For this purpose, ten standards with concentrations between $5 \mu \mathrm{g} / \mathrm{mL}$ and $300 \mu \mathrm{g} / \mathrm{mL}$ solanesol (Aldrich/Sigma, Saint Louis, MO 63178-9916) were prepared in heptane and analyzed by HPLC. Each solution also contained the chromatographic standard (pyrene 50 $\mu \mathrm{g} / \mathrm{mL}$ ), but the pyrene peak was used only to verify the reproducibility of the chromatography and not for normalizing solanesol peak areas. The calibration curve for solanesol quantitation was linear with $R^{2}=0.9997$, and the line intercept was zero.

\section{RESULTS AND DISCUSSION}

The analysis of solanesol was done initially for machine smoked cigarettes using different puffing regimens. At the same time with the analysis of the smoke pad, the cut portion of the cigarette butts was analyzed. Correlation charts between the level of solanesol in smoke as a function of the level in the cigarette butts were obtained. Using these charts the level of solanesol in the cigarette smoke delivered to the human subject were calculated based on the measured level of solanesol in the cigarette butt from the smoker. After this part of the study had been completed, the human subjects smoked the cigarettes and the exhaled smoke was collected and analyzed for solanesol, as previously described. The cigarette butts from each smoker were collected and the solanesol from $1 \mathrm{~cm}$ cut portion was 
Table 2. Dependence lines between solanesol in smoke vs. solanesol in $1 \mathrm{~cm}$ cut of the cigarette butt

\begin{tabular}{l|c|c|c|c}
\hline & & & \multicolumn{2}{|c}{ Range of solanesol in smoke $(\mu \mathrm{g} / \mathrm{cig})$} \\
\cline { 3 - 4 } Cigarette & Equation & $R^{2}$ & Min & Max \\
\hline Cigarette A & $y=4.450 x+50.711$ & 0.9893 & 252 & 642 \\
Cigarette B & $y=4.981 x+6.044$ & 0.9930 & 229 & 634 \\
\hline
\end{tabular}

Table 3. The levels of solanesol in $\mu \mathrm{g} / \mathrm{cig}$ in exhaled smoke for cigarettes evaluated in this study

\begin{tabular}{l|c|c}
\hline Smoker $^{a}$ & $\begin{array}{c}\text { Cigarette A } \\
\mu \mathrm{g} / \mathrm{cig}\end{array}$ & $\begin{array}{c}\text { Cigarette B } \\
\mu \mathrm{g} / \mathrm{cig}\end{array}$ \\
\hline 1 & 131.7 & 137.3 \\
2 & 78.0 & 236.5 \\
3 & 124.8 & 132.2 \\
4 & 116.3 & 123.4 \\
5 & 191.0 & 162.6 \\
6 & 75.2 & 66.9 \\
7 & 116.7 & 120.3 \\
8 & 76.2 & 64.5 \\
9 & 193.9 & 236.2 \\
10 & 82.2 & 156.1 \\
\hline
\end{tabular}

${ }^{a}$ The same human subject smoked the cigarette with no PG and the one with $3 \% \mathrm{PG}$.

Table 4. The calculated levels of solanesol in $\mu \mathrm{g} / \mathrm{cig}$ in the delivered smoke

\begin{tabular}{l|c|c}
\hline Smoker & $\begin{array}{c}\text { Cigarette A } \\
\mu \mathrm{g} / \mathrm{cig}\end{array}$ & $\begin{array}{c}\text { Cigarette B } \\
\mu \mathrm{g} / \mathrm{cig}\end{array}$ \\
\hline 1 & 403.3 & 431.3 \\
2 & 350.2 & 621.5 \\
3 & 382.1 & 426.8 \\
4 & 504.8 & 502.7 \\
5 & 465.7 & 401.5 \\
6 & 423.7 & 503.1 \\
7 & 484.8 & 518.5 \\
8 & 426.5 & 487.4 \\
9 & 488.7 & 614.1 \\
10 & 350.4 & 411.1 \\
\hline
\end{tabular}

analyzed. The level of solanesol in exhaled smoke was then compared with that in the smoke delivered to the human subject. The amount of solanesol retained by the smoker can be calculated from the following difference:

$$
\begin{aligned}
\text { Retention amount }(\mu \mathrm{g} / \mathrm{cig})= & \text { Delivered level } \\
& - \text { Exhaled level }
\end{aligned}
$$

The retention efficiencies (\%) can also be calculated for each smoker using the expression:

$$
\text { Retention \% }=100-\frac{\text { Exhaled level }}{\text { Delivered level }} \cdot 100
$$

Generation of the correlation charts between the level of solanesol on the pad and in the cigarette butt for machine smoked cigarettes

In order to determine the amount of solanesol in the delivered smoke, the regression lines between the level of solanesol in smoke as a function of solanesol in $1 \mathrm{~cm}$ cut portion of the cigarette butts were generated. The equations for the dependence curves for each of the evaluated cigarettes are given in Table 2 . The same table shows the range of solanesol levels in smoke for which the calibrations were generated.

A linear dependence has been previously reported between the nicotine level in the cigarette butt and that collected on a Cambridge pad $(17,18)$. Other studies (19) have shown that a linear dependence is also maintained between the nicotine level in the cigarette butt and the level of other compounds from smoke, such as aldehydes and ketones. Also, linear dependencies were observed between the level of solanesol in the cigarette butt, and compounds in the mainstream smoke such as 4-(methylnitrosamino)-1-(3pyridyl)-1-butanone (NNK), $N$-nitrosonornicotine (NNN), carbon monoxide, isoprene, ethylene and acetaldehyde (20). The linear dependence between the solanesol in the cigarette butt ( $1 \mathrm{~cm}$ cut) and the solanesol in mainstream smoke (as collected on a Cambridge pad) was also demonstrated in a previous paper (8).

\section{Calculation of the retention of solanesol from the evaluated cigarettes}

The levels of solanesol in the exhaled smoke as obtained from the analysis of the Cambridge pads used for the collection of smoke from three cigarettes for each smoker are given in Table 3 for the two evaluated products. The level of solanesol in the delivered smoke were calculated from the level of solanesol measured in $1 \mathrm{~cm}$ cut of the cigarette butts of each smoker (average from three cigarettes) and are given in Table 4. The values for the delivered amount of solanesol for each of the two cigarettes were within the range used for the generation of the calibration curves. From Table 3 and 4 it was possible to calculate using Eqn. [1] the amount of solanesol retained by each smoker. The results are shown in Table 5. An ANOVA single factor analysis showed that the results for the population data are not statistically different $(P=0.17)$ considering a $95 \%$ confidence interval $(\alpha=0.05)$. However, the paired $t$-test performed on data from Table 5 showed that the retention amount from Cigarette $\mathrm{A}$ and that from Cigarette $\mathrm{B}$ are different with $(P=0.035$ for $\alpha=$ $0.05)$. The attempt to determine if there is any correlation between the amount of solanesol delivered from the cigarette to the smoker and the retained amount indicated a weak correlation $(R=0.656$ for Cigarette $\mathrm{A}$ and $\mathrm{R}=$ 0.696 for cigarette $\mathrm{B})$.

The solanesol retention $\%$ for the two cigarettes calculated using Eqn. [2] is given in Table 6. The values of retention $\%$ for Cigarette A varies between $59 \%$ and $82 \%$ from smoker to smoker, and between $60 \%$ and $87 \%$ for the 
Table 5. The amount of solanesol in $\mu \mathrm{g} / \mathrm{cig}$ retained by different smokers

\begin{tabular}{l|c|c}
\hline Smoker & $\begin{array}{c}\text { Cigarette A } \\
\mu \mathrm{g} / \mathrm{cig}\end{array}$ & $\begin{array}{c}\text { Cigarette B } \\
\mu \mathrm{g} / \mathrm{cig}\end{array}$ \\
\hline 1 & 271.6 & 294.0 \\
2 & 272.3 & 385.0 \\
3 & 257.2 & 294.6 \\
4 & 388.5 & 379.3 \\
5 & 274.7 & 238.9 \\
6 & 348.4 & 436.3 \\
7 & 368.1 & 398.2 \\
8 & 350.3 & 422.9 \\
9 & 294.8 & 377.9 \\
10 & 268.1 & 255.0 \\
Average & 309.4 & 348.2 \\
RSD\% & 15.8 & 20.4 \\
Minimum & 257.2 & 238.9 \\
Maximum & 388.5 & 436.3 \\
\hline
\end{tabular}

Table 6 . The retention $\%$ of solanesol by different smokers

\begin{tabular}{l|c|c}
\hline Smoker & $\begin{array}{c}\text { Cigarette A } \\
\%\end{array}$ & $\begin{array}{c}\text { Cigarette B } \\
\%\end{array}$ \\
\hline 1 & 67.4 & 68.2 \\
2 & 77.7 & 61.9 \\
3 & 67.3 & 69.0 \\
4 & 77.0 & 75.4 \\
5 & 59.0 & 59.5 \\
6 & 82.2 & 86.7 \\
7 & 75.9 & 76.8 \\
8 & 82.1 & 86.8 \\
9 & 60.3 & 61.5 \\
10 & 76.5 & 62.0 \\
Average & 72.6 & 70.8 \\
RSD\% & 11.7 & 14.5 \\
Minimum & 59.0 & 59.5 \\
Maximum & 82.2 & 86.8 \\
\hline
\end{tabular}

product with 3\% PG (Cigarette B). The average values for retention $\%$ are closer between the two evaluated cigarettes compared to the delivered amount of solanesol, being $72.6 \%$ and $70.8 \%$, respectively. The ANOVA single factor analysis indicated no significant differences in the retention $\%$ of solanesol for the two cigarettes $(P=0.68$ for $\alpha=$ 0.05 ). The paired $t$-test performed on data from Table 6 showed that the retention \% from Cigarette $\mathrm{A}$ and that from Cigarette $\mathrm{B}$ are not significantly different with $(P=0.465$ for $\alpha=0.05$ ). The attempt to determine if there is any correlation between the amount of solanesol delivered from the cigarette to the smoker and the retained \% indicated that there is no correlation $(R=-0.302$ for Cigarette $\mathrm{A}$ and $R=0.005$ for Cigarette $\mathrm{B})$.

\section{CONCLUSIONS}

This study reports the level of solanesol in exhaled cigarette smoke for two cigarettes with identical blend, one containing no PG and the other containing 3\% PG. The amount of solanesol and the retention \% of solanesol from the two cigarettes are not significantly different as shown using
ANOVA single factor analysis. Directionally, the amount of solanesol retained by the smokers (per cigarette) was higher for the 3\% PG product with an average $348 \mu \mathrm{g} / \mathrm{cig}$ and an average of $309 \mu \mathrm{g} / \mathrm{cig}$ for commercial product that does not contain PG. The retention \% of solanesol from the commercial cigarette showed an average of $72.6 \%$ with $11.7 \%$ relative standard deviation, and an average retention of $70.8 \%$ with $14.5 \%$ relative standard deviation for the cigarette with $3 \%$ added PG. The ANOVA single factor analysis indicated no significant differences in the retention $\%$. No correlation was found between the amount of solanesol delivered from the cigarette to the smoker and the solanesol retained $\%$.

\section{REFERENCES}

1. Baker, R.R. and M. Dixon: The retention of tobacco smoke constituents in the human respiratory tract; Inhalat. Toxicol. 18 (2006) 255-294.

2. Ogden, M.W. and K.C. Maiolo: Collection and determination of solanesol as a tracer of environmental tobacco smoke in indoor air; Environ. Sci. Technol. 23 (1989) 1148-1154.

3. Tang, H., G. Richards, C.L. Benner, J.P. Touminen, M.L. Lee, E.A. Lewis, L.D. Hansen, and D.J. Eatough: Solanesol, a tracer for environmental tobacco smoke particles; Environ. Sci. Technol. 24 (1990) 848-852.

4. McAughey, J.J., D.A. Knight, A. Black, and C.J. Dickens: Environmental tobacco smoke retention in humans from measurements of exhaled smoke composition; Inhalat. Toxicol. 6 (1994) 615-631.

5. Armitage, A.K., M. Dixon, B.E. Frost, D.C. Mariner, and N.M. Sinclair: The effect of inhalation volume and breath-hold duration on the retention of nicotine and solanesol in the human respiratory tract and on subsequent plasma nicotine concentrations during cigarette smoking; Beitr. Tabakforsch. Int. 21 (2004) 240-249.

6. Pillsbury, H.C., C.C. Bright, K.J. O'Connor, and F.H. Irish: Tar and nicotine in cigarette smoke; J. Assoc. Off. Anal. Chem. 52, (1969) 458-462.

7. Armitage, A.K., M. Dixon, B.E. Frost, D.C. Mariner, and N.M. Sinclair: The effect of tobacco blend additives on the retention of nicotine and solanesol in the human respiratory tract and on subsequent plasma nicotine concentrations during cigarette smoking; Chem. Res. Toxicol. 17 (2004) 537-544.

8. Moldoveanu, S.C. and W. Coleman III: A pilot study to assess solanesol levels in exhaled cigarette smoke; Beitr. Tabakforsch. Int. 23 (2008) 144-152.

9. Mullard, G., P. Biggs, and D.C. Mariner: The effects of mouth-hold time and controlled inhalation depth on measured tobacco smoke retention in human cigarette smoking; Meeting of the Aerosol Soc. and Lung Modelling, Sheffield, U.K, 2004.

10. Sinclair, N.M., B.E. Frost, and D.C. Mariner: Factors related to nicotine physio-chemistry and retention in human smokers; CORESTA Congress, 1998, Brighton, U.K. Abstr. ST19, p 167.

11. Bernstein, D.M.: A review of the influence of particle size, puff volume, and inhalation pattern on the deposition of cigarette smoke particles in the respiratory 
tract; Inhalat. Toxicol. 16 (2004) 675-689.

12. Robinson, R.J. and C.P. Yu: Theoretical analysis of hygroscopic growth rate of mainstream and sidestream cigarette smoke particles in the human respiratory tract; Aerosol Sci. Technol. 28 (1998) 21-32.

13. Cinkotai, F. F.: The growth of cigarette smoke particles suspended on fine platinum wire in moist air; Beitr. Tabakforsch. 4 (1968) 189-195.

14. Bodnar, J.A., T.J. Collins, S.M. DeBusk, and M.F. Borgerding: Estimation of 'tar' and nicotine yields from individual cigarettes based on filter analysis after smoking; $58^{\text {th }}$ Tobacco Science Research Conference, Program Booklet and Abstracts, Vol. 58, Paper No. 8, 2004, p 25.

15. Ogden, M.W. and K.C. Maiolo: Comparison of GC and $\mathrm{LC}$ for determining solanesol in environmental tobacco smoke; LC-GC 10 (1992) 459-462.

16. Zhou, H.-Y and C.-Z. Liu: Rapid determination of solanesol in tobacco by high-performance liquid chromatography with evaporative light scattering detection following microwave-assisted extraction; J. Chromatogr. B 835 (2006) 119-122.

17. St.Charles, F.K.: A robust method for determining consumer smoked cigarette yields from filter analytical data; $55^{\text {th }}$ Tobacco Science Research Conference, Program Booklet and Abstracts, Vol. 55, Paper No. 92, 2001, pp. 73-74.
18. Bodnar, J.A., T.J. Collins, S.M. DeBusk, and M.F. Borgerding: Estimation of 'tar' and nicotine yields from individual cigarettes based on filter analysis after smoking; $58^{\text {th }}$ Tobacco Science Research Conference, Program Booklet and Abstracts, Vol. 58, Paper No. 8, 2004, p 25.

19. Moldoveanu, S., W. Coleman III, and J. Wilkins: Determination of carbonyl compounds in exhaled cigarette smoke; Beitr. Tabakforsch. Int. 22 (2007) 346-357.

20. Feng. S., S.E. Plunkett, K. Lam, S. Kapur, R. Muhammad, Y. Jin, M. Zimmermann, P. Mendes, R. Kinser, and H.J. Roethig: A new method for estimating the retention of selected smoke constituents in the respiratory tract of smokers during cigarette smoking; Inhalat. Toxicol. 19 (2006) 169-179.

Address for correspondence:

Serban C. Moldoveanu

R.J. Reynolds Tobacco Co.

950 Reynolds Blvd

Winston-Salem, NC 27105,

USA

E-mail:MoldovS@RJRT.com 